Consultations with outside scientific institutions will be resorted to, both to ensure against overlapping and with the view of utilising such of their researches and experiments as appear likely to prove of value to the Naval Service.

At present there exists under the Department a naval research laboratory at Shandon. This establishment was set up during the war with the primary object of investigating methods of counteracting the enemy's submarine menace. It has performed, and is performing, good service; but Shandon is a great distance from the experimental schools, the various scientific institutions, and the Admiralty, and it has therefore been decided that, so soon as suitable accommodation can be provided elsewhere, such of the work as requires sea environment, together with the scientific personnel associated with it, will be removed to a suitable existing naval establishment, and the remainder, which does not in its early stages require a sea environment, will be transferred to a naval research institute. This institute, under the Director of Scientific Research. will adjoin the National Physical Laboratory at Teddington. It will be entirely controlled by the Admiralty, but its close association with the National Physical Laboratory will offer exceptional facilities for co-operation, and the staff of the research institute will have the advantage of personal acquaintance with the work being carried out at the laboratory. The Department of Scientific and Industrial Research will be consulted in all cases when the results of investigations are likely to be of use to the general community.

To ensure effective co-operation and contact with naval thought, naval officers will frequently visit the research institute, and the scientific staff will work for lengthy periods at naval establishments, and at times go to sea

\section{Education and Science in the Civil Service Estimates for I920-2I.}

THE Estimates for Civil Services for the year ending March 31, I92 I (Class IV.: Education, Science, and Art), have now been published. Among the increased grants compared with those of last year are :-Board of Education, I2,983,094l.; British Museum, 74,5Igl.; Scientific Investigation, etc., 81,442l.; Scientific and Industrial Research, 246,845l.; Public Education (Scotland), 2,200,00ol.; Public Education (Ireland), $185,735 \mathrm{l}$.; and Science and Art (Ireland), 20,9I7l. As the Geological Museum and Geological Survey are now under the Department of Scientific and Industrial Research, their grants of $7560 l$. and $30,043 l$. respectively represent part of the increase of $246,845 l$. to that Department. The grant for scholarships, exhibitions, and other allowances to students in technical schools and colleges is increased from $17,460 l$. to $34,35 \mathrm{ol}$. In addition, there are new grants of ${ }_{15}, 000 l$. for scholarships tenable at universities, and expenses incidental to them, and $250,000 l$. to local education authorities for maintenance allowances at places of higher education. The total amount of the grants in aid of universities, colleges, medical schools, and like institutions in the United Kingdom is about $1,000,000 l$.; there is also a special grant of $196,000 l$. for extraordinary expenditure. The grant for assistance towards the higher education of ex-officers and men of like standing is $3,000,000 l$., compared with $2,000,000 l$. for 1910-20. The grant under the Royal Society shows an increase of $9000 l$., and includes $2000 l$. for subscriptions to international NO. 2634 , VOL. IO5] research associations. The subjoined summary and details are extracted from the Estimates :-

SynOPSIS.

United Kingdom and England.

Board of Education ...

$\begin{array}{lllll}\text { British Museum } & \ldots & \ldots & \ldots & \ldots \\ & \ldots & \ldots & \ldots & \end{array}$

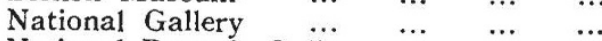

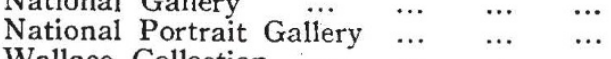

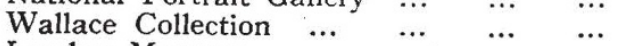

$\begin{array}{lllll}\text { London Museum } & \ldots & \cdots & \ldots & \ldots \\ \end{array}$

Imperial War Museum $\ldots \quad \ldots \quad \ldots$

$\begin{array}{lll}\text { Scientific Investigation, etc. } & \ldots & \ldots \\ \text { Scientific and Industrial Research } & & \ldots\end{array}$

Universities and Colleges, United Kingdom, and Intermediate Education,

Wales

Universities, etc., Special Grants $\cdots \quad \cdots$

Serbian Relief Fund (maintenance and education of young Serbians in this country)

\section{Scotland.}

Public Education

National, Galleries

$\begin{array}{llll} & \ldots & \ldots & \ldots \\ \cdots & \cdots & \cdots & \cdots\end{array}$
$45,755,567$
294,233
29,956
9,824
${ }^{1} 5,953$
5,412
50,000
208,416
$5^{18,298}$

945,700

196,000

25,000

Ireland.

Public Education

Intermediate Education $\quad \ldots \quad c k \quad \ldots$

Endowed Schools Commissioners

$\begin{array}{lllll}\text { National Gallery } & \ldots & \ldots & \ldots & \ldots\end{array}$

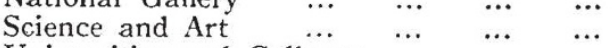

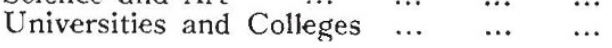

Details.

$6,877,220$

II ,66I

$3,35^{8,37 \text { I }}$

90,000

1,042

4,650

211,415

86,000

$5^{8,694,718}$

Royal Society :

Scientific Investigation, etc.

(i) Grant in aid of :-

Scientific investigations undertaken with the sanction of a Committee appointed for the purpose (including nonrecurrent grant of $5000 l$.) $\ldots$... I , 000

Scientific publications $\ldots . \ldots 1,000$

Subscriptions to international

research associations $\quad \ldots 2,000$

(ii) Grant in aid of salaries and other expenses of the Magnetic Observatory at Eskdalemuir

\section{Total for Royal Society}

$\cdots$
$\ldots$

Royal Geographical Society

Marine Biological Association of the United Kingdom $\ldots$... $\quad \ldots \quad \ldots$

Royal Society of Edinburgh $\quad \ldots . \quad \ldots$ Scottish Meteorological Society $\ldots .$. Royal Irish Academy

Royal Irish Academy of Müsic

Royal Zoological Society of Ireland

Royal Hibernian Academy

British School at Athens $\quad \cdots, \ldots$

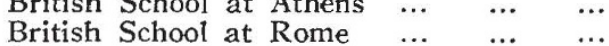

Royal Scottish Geographical Society

$\begin{array}{lcc}\text { National Library of Wales } & \ldots & \ldots \\ \text { National Museum of Wales } & \ldots & \ldots\end{array}$

Solar Physies Observatory $\quad \ldots . \quad \ldots$

North Sea Fisheries Investigation

Imperial Mineral Resources Bureau
I 4,000

\begin{tabular}{r}
1,000 \\
\hline 15,000 \\
\hline 1,250 \\
1,000 \\
600 \\
100 \\
1,600 \\
300 \\
500 \\
300 \\
500 \\
500 \\
200 \\
12,000 \\
25,500 \\
3,000 \\
1,250 \\
10,750
\end{tabular}


Royal Academy of Music $\quad \ldots \quad \ldots \quad \ldots$

Royal College of Music $\quad \ldots \quad \ldots \quad \ldots$

Medical Research Council ... $\quad \ldots \quad \ldots$

British Institute of Industrial Art $\quad \ldots$

Edinburgh Observatory

Department of Scientific and Industrial Research.

Salaries, wages, and allowances $\ldots \quad \ldots \quad \quad 29,235$

Travelling and incidental expenses

Grants for Investigation and Research :
(I) Investigations carried out by learned

(I) Investigations carried out by learned
and scientific societies, etc. ... ...

(2) Investigations directly controlled the Department of Scientific and Industrial Research

(3) Students and other persons engaged in research

(4) Expenses of Research $\dddot{B}$ Boards for coordination of Government research ...

$$
\begin{array}{lllll}
\text { Total } & \ldots & \ldots & \ldots & \ldots
\end{array}
$$

Fuel Research Station

Geological Survey of $\dddot{G}$ reat $\dddot{B}$ ritain $\cdots \quad \cdots$

National Physical Laboratory ... ...

Appropriations in Aid :-

Contributions of co-operating bodies ...

Refund of unexpended balance of grants

Testing fees at Fuel Research Station ...

Sales of by-products at Fuel Research Station

Testing fees at the National Physical Laboratory, charges for special investigations, and repayments by the Road Board, India Office, etc., for services rendered by the National Physical Laboratory

Balance of accrued interest at March $\ddot{3}$, $192 \mathrm{I}$, on the Fund of the Imperial Trust for the encouragement of scientific and industrial research, for which $1, \infty 00,000 l$. was voted in $\begin{array}{lllllll} & 1917-18 & \ldots & \ldots & \ldots & \ldots & \ldots\end{array}$

Total for Appropriations in Aid Universities and Colleges, United Kingdom.

Birmingham University

Bristol University

Bristol Merchant Venturers' $\ldots$ Technical $\begin{array}{llllll}\text { College } \quad \ldots & \ldots & \ldots & \ldots & \ldots\end{array}$

Cambridge University, Medical $\dddot{\text { Depart- }}$

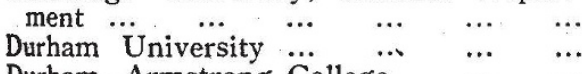

$\begin{array}{lll}\text { Durham, Armstrong College } & \ldots & \ldots \\ \text { Durham College of Medicine } & \ldots & \ldots\end{array}$

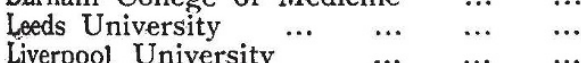

$\begin{array}{llll}\text { Liverpool University } & \ldots & \ldots & \ldots\end{array}$

$\begin{array}{llll}\text { London University } \ldots & \ldots & \ldots & \ldots \\ \text { London, Bedford College } & \ldots & \ldots & \ldots\end{array}$

, East London College $\ldots . .$.

, Imperial College of Science and Technology

" King's College, Household and Science Department ... ...

" King's College, including King's College for Women$$
\text { … } \quad \cdots
$$

29,235
$1,95^{\circ}$

${ }_{3}, 800$

40,928

38,300

200,000

293,028

40,882

7,560

30,043

203,000

$\mathrm{I}, 55^{\circ}$

300

I,000

2,500

55,000

$\frac{27,050}{87,400}$

35,000

x 7,000

2,000

8,500

2,000

22,000

3,800

33,000

40,000

8,000

I 3,000

II, 000

$5^{2,000}$

4,000

25,000

1 Services rendered without payment for other Government Departments we estimated as follows:- Admiralty. 7,500l.; Air Ministry, $40.000 l$. Ministry of Munition:, 7,000l, War Office, 2, $150 l$; H.M. Office of Works Advisory Council, 8,000l.

NO. 2634 , VOL. IO5]
London, School of Economics $\quad \ldots \quad \ldots \quad \ldots r$

School of Oriental Studies $\quad \ldots . \quad 4,000$

University College $\quad \ldots \quad \ldots \quad 39,000$

Westfield College ... ... .... 3,000

Charing Cross Hospital Medical School $\quad \ldots \quad$... $\quad . . \quad \ldots$

King's College Hospital Medical School $\quad \ldots \quad$... $\quad \ldots \quad \ldots$ London Hospital Medical College Middlesex Hospital Medical School $\ldots \ldots$... $\ldots$. $\ldots$ Royal Dental Hospital, School of

(Royal Free Hospital), School of Medicine for. Women ... ...

St. Bartholomew's Hospital Medical School ... ... ...

St. George's Hospital Medical School $\quad . . \quad$... $\quad \ldots \quad \ldots$ St. Mary's Hospital Medical School $\ldots \ldots$... … St. Thomas's Hospital Medical $\begin{array}{cccc}\text { School } & \ldots & \ldots & \ldots\end{array}$ University College Hospital Medical School ... ... ...

Westminster Hospital Medical $\begin{array}{lllll}\text { School } & \ldots & \ldots & \ldots & \ldots\end{array}$

$\mathrm{I}, \mathrm{000}$

700

6,000

2,000

I,,$\infty 0$

4,000

5,000

700

I,900

4,500

$\mathrm{I}, \mathrm{I00}$

4,000

300

$\begin{array}{lcrrr}\text { Manchester University } & \ldots & \ldots & \ldots & \text { ( } \\ \text { Manchester College of Technology } & \ldots & 40,000 \\ \end{array}$

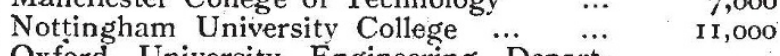

Oxford University Engineering Depart-

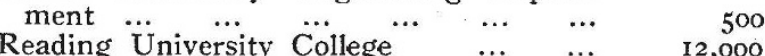

$\begin{array}{llll}\text { Reading University College } & \ldots & \ldots & \text { 12, } 000\end{array}$

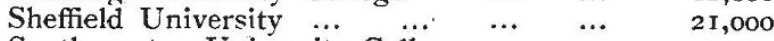

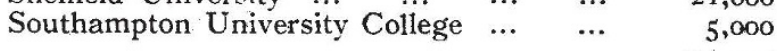

$\begin{array}{rlll}\text { Total England } \quad \ldots & \ldots & 46 \mathrm{r}, 000\end{array}$

$\begin{array}{lllll}\text { University of Wales } \ldots & \ldots & \ldots & \ldots & 6,500\end{array}$

Aberystwyth University College $\ldots . \quad \ldots \quad 14,000$

$\begin{array}{llll}\text { Bangor University College } & \ldots & \ldots & 14,000 \\ \text { Cardif } & & \end{array}$

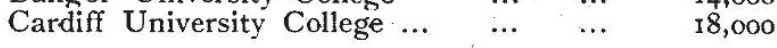

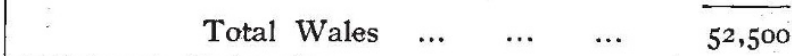

$\begin{array}{lllll}\text { Edinburgh University } & \ldots & \ldots & \ldots & 53,000\end{array}$

$\begin{array}{llllll}\text { Glasgow University } \ldots & \ldots & \ldots & \ldots & 48,000\end{array}$

Glasgow Royal Technical College $\quad \ldots \quad 3,000$

Aberdeen Universicy ... $\ldots$... $\ldots$ 32,000

St. Andrews University, including Dundee

$\begin{array}{lllll}\text { University College } \ldots & \ldots & \ldots & \ldots & 29,000\end{array}$

Total Scotland ${ }^{2} \quad \ldots \quad \ldots \quad \overline{165,000}$

Belfast, Queen's University $\quad \ldots \quad \ldots \quad \ldots \quad 8,000$

$\begin{array}{llllll}\text { Cork University College } & \ldots & \ldots & \ldots & 6,000\end{array}$

$\begin{array}{lllll}\text { Dublin University College } & \ldots & \ldots & \ldots & \text { 10,000 }\end{array}$

$\begin{array}{llll}\text { Galway University College } & \ldots & \ldots & 3,000\end{array}$

Total Ireland $^{3} \quad \ldots \quad \ldots \quad \overline{27,000}$

Universities and Colleges, United King-

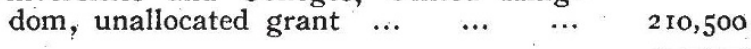

Total for Universities and

Colleges, United Kingdom,

Grant in Aid

... ...

$9^{16,000}$

2 This sum includes $42,000 l$. payable to Scottish Universities under Section 25 of the Universities (Scotland) Act, $188 \mathrm{~g}$, and is in addition to an annual sum of 30,000 . payable to these Universities from the Local Taxation (Scotland) Account under Section 2(2) of the Education and Local Taxation Account (Scotland) Act, r892.

3 In addition to $84.000 l$. provided in Class IV., 18.
4 This sum, together with $84,000 \%$ provided in Class IV., 18 , is intended 4 This sum, together with $84,000 l$ provided in Class IV., 18 , is intended
to raise to $x, 000,000 l$. the total amount of the grants paid out of the to raise to $1, \infty 00,000 /$. the total amount of the grants paid out of the
Exchequer during the year. 1920-21 for the maintenance of University Institutions in the United Kingdorn. 